\title{
Em louvor do cosmopolita irônico: Nacionalismo, o "judeu errante" e a cidade pós- nacional
}

\author{
N igel Rapport \\ Professor do D epartmento de A ntropologia Social - University of St. A ndrews \\ E scócia
}

RESUMO: Na medida em que os antropólogos passaram a descrever a crescente normatividade do movimento global ea conseqüente hibridização, criolização, sincronicidade e compressão do multiculturalismo, "diáspora" tornou-se uma palavra-chave no arsenal da disciplina. Este texto aborda um traço particular dessa abordagem diaspórica, que diz respeito ao "judeu errante" exílico. Partindo do exame do "judeu" no discurso do nacionalismo moderno, desenvolve um discurso possível de urbanismo pós-nacional, a fim de concluir com uma abordagem etnográfica de vidas judaicas no ambiente canadense contemporâneo da área urbana da província de Newfoundland. Enquanto o idioma do "judeu errante" diz pouco sobre o conteúdo das vidas individuais de fato existentes, 0 que será que, entretanto, contém em termos de prescrição política? Qual a mensagem política embutida na noção de cosmopolitismo e transnacionalismo universal (judaico), e como esse tipo ideal pode ser empregado idealisticamente pela antropologia em favor da crítica cultural? Partindo do idioma do "judeu errante", este texto passa, assim, a delinear a "hospedagem mútua" ["mutual guesting"] como conceptualização de procedimentos sociais justos num novo sistema mundial.

PALAVRAS-CHAVE: globalização, pós-nacionalismo, cosmopolitismo, diáspora, judeus, discurso, ironia, urbanismo, Newfoundland. 
Não foi tanto a perseguição que fez dos judeus uma nação de errantes, mas a esperança.

(Bermant, 1998: Introdução)

Será que há mais do que corretismo político e do que o modismo das inversões - desconstrução das hierarquias e preferência pelo que é marginal - , na visão de que a diáspora e o pária são centrais na experiência contemporânea? Segundo Iaian Chambers, por exemplo, "ser estrangeiro num país estranho (...) talvez seja uma condição típica da vida contemporânea" (1994: 18)¹. Ele continua:

As crônicas sobre diásporas - a do Atlântico negro, do judeu metropolitano, os deslocamentos rurais em massa - constituem o movimento de fundo da modernidade. Esses testemunhos históricos colocam em questão e minam qualquer senso de origem simples ou ingênuo, de tradição e de movimento linear. (...) A percepção do migrante de ser desenraizado, de viver entre dois mundos, entre um passado perdido e um presente não-integrado, talvez seja a metáfora mais adequada dessa condição (pós-moderna). (: 16, 27)

As migrações de negros, judeus e, por exemplo, dos irlandeses, repentinamente se transformam em "condições típicas", "metáforas adequadas" e "movimentos de fundo" autênticos.

Mas isso não é apenas a visão do antigo centro. Os próprios viajantes hoje em dia consideram suas experiências "sintomas típicos de uma condição moderna ao mesmo tempo local e universal" (Nkosi, 1994: 5). Segundo Lewis Nkosi, a sensação de falta de lar [homelessness] mantémse para o africano, esteja ele exilado do seu continente em conseqüência do colonialismo, ou reconciliado com sua terra via o momento da póscolonialidade. D e fato, não haveria volta ao lar para ninguém no mundo moderno, porque a "consciência moderna" seria em si "alienada ou marginalizada", suportando a instabilidade radical da ruptura, do abandono, da partida e do deslocamento. Conseqüentemente, o exílio dos africanos seria 0 tema central da cultura moderna ${ }^{2}$. 
Revista de Antropologia, São Paulo, USP, 2002, v. 45 no 1.

Algo semelhante vale para os irlandeses. Conforme D eclan Kiberd (1998), o desenraizamento e reorientação longamente experienciados por esse povo - deslocando-se de ruralidades remotas para as cidades do interior da Grã-Bretanha e dos Estados Unidos - acabaram por constituir, para milhões, as modalidades centrais do "progresso" no século XX. Longe de retrógrados, conclui Kiberd, os irlandeses estiveram entre os primeiros a lidar com "o impasse modernizador" e, desde meados do século XIX, encontrar-se-iam entre os povos mais avançados e orientados para o futuro.

Isso para não falar dos judeus. $O$ escritor tcheco Milan Kundera, exilado da Europa $O$ riental na Europa O cidental, define como "grandes figuras judaicas" aquelas que demonstraram um "sentimento excepcional" por aquilo em nome do qual toda a E uropa hoje em dia trabalha e que estima: nomeadamente, uma política doméstica "concebida não como território mas como cultura" (1990: 157). Exilados de sua terra de origem e alçados acima de paixões nacionalistas, os judeus, argumenta Kundera, exemplificariam uma possível identidade transnacional.

Os antropólogos tampouco relutaram em teorizar a respeito da normatividade dos movimentos globais e a conseqüente hibridização, criolização [creolization], sincronicidade e compressão do multiculturalismo. "Diáspora" tornou-se uma palavra-chave no arsenal da disciplina (Tedlock, 1996), com estudos sobre a maneira como membros de comunidades diaspóricas preservam e regeneram imaginativamente identidades particulares, mantendo um senso de diferenciação mesmo que separados dos seus terrenos "pátrios", e dispersos. Lares ideais são indiretamente experienciados através do mito, através do recontar de histórias sobre práticas e façanhas aborígenes (para retornarem em algum momento do futuro), enquanto a solidariedade social é assegurada através de complexas formas culturais transnacionais que transmutam continuamente espaço em lugar. De fato, ser desenraizado, sentir-se em casa entre dois mundos, habitar um ambiente cultural entre um passado perdido e um presente fluido: hoje em dia esses aspectos são 
encarados como descritores mais precisos da vida social do que as antigas abordagens sobre stasis e estrutura sociocultural (Rapport \& Dawson, 1998). A vida é uma viagem, a consciência, uma viagem; 0 pensamento e a escrita são viagens, a antropologia como tal é uma viagem.

Os perigos e obstáculos desse tipo de abordagem sociocultural são tão visíveis quanto a sua elegância. 0 nível de generalidade ao qual ela pode recorrer - o emprego da generalização global per se - facilmente acarreta afirmações que são verdadeiras apenas enquanto estiverem ausentes o detalhe e as sutilezas implícitas na apreciação de vidas individuais. 0 essencialismo de se tratar as experiências "judia", "irlandesa" ou "negra" como uniformes e, num segundo momento, como arquétipos da condição humana contemporânea, pode acabar por fazer com que se reiterem os mesmos tipos de estereótipos fatais, categóricos que se pretendiam desconstruir: a periferia torna-se centro (e essência). A panacéia analítica da migração e da transnacionalidade corre, em suma, o risco de eufemizar toda a experiência sociocultural como conjunto de versões de um mesmo fenômeno diaspórico.

Diante disso, o que viso, no presente texto, é assumir um aspecto particular dessa abordagem geral - aquele referido ao "judeu errante" exílico -, admitindo-o como idioma que, se pouco revela sobre 0 conteúdo das vidas judaicas de fato, pode servir para a descrição e prescrição políticas contemporâneas. Visto que a sociedade é uma construção discursiva contínua, que mensagem política a noção de cosmopolitismo e transnacionalismo judaico carrega consigo, qual 0 trabalho social que o idioma efetiva? Como a noção, enquanto tipo ideal, pode ser utilizada idealisticamente pela antropologia em favor da crítica cultural, em defesa de procedimentos justos num novo "sistema mundial"? O texto parte de um exame do "judeu" no discurso do nacionalismo moderno, passando a um discurso possível de urbanismo pósnacional, para concluir com uma abordagem etnográfica de vidas judaicas na área urbana da província de Newfoundland contemporânea. 
Revista de Antropologia, São Paulo, USP, 2002, v. 45 no 1.

\section{A missão do judeu errante}

Não é necessário retomar o papel de pária atribuído aos "judeus" no projeto moderno de nacionalismo: o desejo de inculcar uma homogeneidade nacional-cultural como via de estabilidade social e crescimento econômico (G ellner, 1983). A rendt descreve os judeus como "elemento não-nacional" incongruente, ambíguo e enigmático "num mundo de nações crescentes ou existentes"; mundo no qual a nacionalidade estaria fadada a tornar-se a base suprema da autoconstituição grupal (1962: 22). Segundo Bauman (1989), os judeus foram representados, em sua ubiqüidade e dispersão, como "nação internacional" ou "nação nãonacional" que ameaçava constantemente, com relatividade e delimitação, 0 critério de nacionalidade, que visava determinar a auto-identidade de forma clara, conclusiva e absoluta. Nunca completamente pertencentes aos países em que viviam, os judeus eram um inimigo interno: "eles minavam a diferença genuína entre anfitriões e hóspedes, entre 0 nativo e 0 estrangeiro" (: 52). Ao formular questões nunca antes colocadas, tratando o familiar como exótico, os judeus passaram a ser associados a valores não-patrióticos referentes ao universalismo, ao cosmopolitismo liberal e à humanidade-como-tal. Sua flexibilidade e adaptabilidade, sua inanidade nacional os tornaram desprezíveis.

Conseqüentemente, o lugar especial reservado ao judeu na ideologização (e demonização) dos dois grandes experimentos nacionalistas do século XX: o nacional-socialismo alemão e o republicanismo soviético. A "questão judaica" preocupou, por exemplo, Lenin desmesuradamente (como tinha feito com Marx e com Stalin); e ele continuamente buscou maneiras de normalizar a "identidade nacional judaica", inserindo, assim, judeus outrora cosmopolitas e desenraizados numa democracia socialista (1974). Nesta, ao contrário, nações poderiam se amalgamar, e 0 judaismo e a yiddishk eit conseqüentemente desapareceriam. De fato, o sionismo era uma manifestação reacionária do nacionalismo burguês, concluía Lenin, mas se era para os judeus assumirem direitos e 
liberdades nacionais no interior da USSR - uma pátria nacional em Birobidzhan, na Sibéria, por exemplo (Weinberg, 1998) - , então 0 sionismo deitaria as bases para a participação deles numa união dos povos soviéticos: para congregarem-se adequada e orgulhosamente numa herança cultural soviética totalizante. 0 anti-semitismo seria eliminado, animosidades nacionais e particularismos raciais não se exacerbariam, e haveria poucos obstáculos para a união de todos os trabalhadores contra as ordens internacionais reacionárias - culturas e classes capitalistas, autocráticas e clericais.

D essa fetichização nacional-cultural pode, contudo, restar algo de positivo, não obstante as tragédias do hitlerismo e do stalinismo. Há um sentimento positivo e esperançoso, por exemplo, na descrição paradoxal que Kundera faz do Estado moderno de Israel como "verdadeiro coração da Europa"; um "coração peculiar localizado fora do corpo". O que isso não revelaria acerca de uma possível natureza imaginativa da identidade, acerca da sua separação em relação ao território e ao institucionalismo cultural, e acerca das bases associativas do pertencimento à comunidade (Kundera, 1990: 157)? Será que de uma Europa pósnacional não poderia emergir o imaginário de políticas construídas com base na participação voluntária e múltipla de agentes individuais que flutuam livremente?

George Steiner (1998) aborda a questão da forma talvez mais eloqüente. Pondera: como será que ele, judeu no final do século mais sangrento de dois milênios de sangrentas perseguições e pogroms, deveria interpretar hoje em dia a noção de que os judeus seriam um "povo eleito"? Possivelmente, que existiria uma maneira de construir a ordem sócio-política sem se basear num "pensamento de identidade" categorial. Derivar a "nobreza", a "verdadeira 'eleição" do judeu da "condição peregrina, impotente", que lhe foi atribuída pela rotulação discriminatória, poderia significar apontar para um não-nacionalismo; para um pósnacionalismo no qual os seres humanos aspirariam a "não torturar outros seres humanos, a não fazer deles indivíduos sem lar [homeless], como ele [o judeu] tão freqüentemente foi”. E Steiner conclui: 
Revista de Antropologia, São Paulo, USP, 2002, v. 45 no⒈

Será que anossa verdadeira missão poderia ser não a de um Estado-nação - tão abominável ou corajoso, tão corrupto ou inventivo como qualquer outro - , mas a de hóspedes (e que sejam indesejados) entre os homens?

É que apenas como hóspedes uns dos outros, e desse pequeno planeta, os homens escaparão à destruição. (1998: 15)

Ressalto novamente que não estou interessado tanto em explorar a "judaicidade" (ou particularidade) específica dessa tese, quanto as suas proposições fundamentais (e possivelmente gerais): o estar em casa no mundo através de um cosmopolitismo universal, no qual o pertencimento dos indivíduos não se deve a "sangue e solo" ou a qualquer tipo de autoctonia fundamental ou fundamentalista. $\mathrm{O}$ indivíduo pertence em trânsito, está em casa em movimento e reside, de direito (institucionalizado por procedimentos justos), voluntariamente, numa sucessão de ambientes socioculturais em relação aos quais negocia, por meio de contratos mais multiplex ou mais simplex , uma associação por um período mais ou menos longo de tempo, com propósitos mais ou menos nitidamente definidos.

A tese de Steiner sobre a hospedagem mútua parece-me imbuída de sentimentos estimáveis, além de oferecer uma imagem utópica. Mas será que pode ser mais do que isso? Em particular, é possível transformarse num projeto antropológico viável - o de desenvolver um modelo de pós-nacionalismo com base no transnacionalismo? Afinal, o mundo dificilmente está necessitado de ilusões utópicas ou de fantasias aforísticas ${ }^{3}$; e no passado os antropólogos freqüentemente, com alguma razão, evitaram o comprometimento e a crítica de cunho político. Mas, depois disso, ao lado do recente florescimento de estudos antropológicos sobre nacionalismo, houve o desenvolvimento "perturbador" (como descreve Jonathan Spencer - 1997: 392) da tendência de antropólogos serem menos caridosos do que habitualmente em relação às convicções nacionalistas dos seus informantes, pouco importando o quão profundas fossem essas convicções. O nacionalismo, sugere Spencer, ocupa uma posição especialmente sensível, mesmo na consciência profissional- 
antropológica, devido à gravidade dos crimes que foram e continuam a ser cometidos em seu nome, e por causa das reivindicações pomposamente especiosas por autoctonia e autenticidade às quais ele é comumente associado. A reflexividade, que estimulou a antropologia desde a sua inflexão literária [literary turn], também significa que os antropólogos agora estão menos dispostos a - ou capazes de - esconderse atrás de asserções de "relativismo cultural" quando o assunto são os seus próprios julgamentos (Rapport, 1998a). Advém daí o meu próprio empenho pelo semi-utopismo ${ }^{4}$.

\section{Cosmopolitismo e a metrópole pós-nacional}

Um dos principais crimes atribuídos mais comumente a "judeus" pelos nacionalistas (tanto nazistas quanto soviéticos, por exemplo) é 0 cosmpolitismo. Concebendo-se como operando num espaço global, os judeus teriam pouca ligação ou lealdade para com qualquer espaço local particular. Encontram-se ecos disso, obviamente, em relação a vários grupos de imigrantes, cujos centros de referência são colocados em questão pelos chauvinistas locais. D a mesma forma como Norman Tebbit, membro infame do gabinete conservador de Thatcher nos anos 80, difamou os imigrantes asiáticos da $\mathrm{G}$ rã-Bretanha duvidando que esses apoiariam a Inglaterra se o Paquistão, o Sri Lanka ou a Índia fossem adversários do país no crick et (Werbner, 1996), arquinacionalistas vêem no "cosmopolitismo judaico" razões para suspeita. Se o "judeu" está presente na maioria dos países do mundo (mesmo que não esteja em casa em nenhum deles), então, num certo sentido, o "judeu" é membro da maioria dos países. Certamente ele não se limita desnecessariamente em termos de cidadania; e será que, então, não é provável que suas ligações, redes e relações transnacionais superem em significância as ligações, redes e relações meramente nacionais e provincianas? Como resume 0 OED [0 x ford E nglish D ictionary] de forma sucinta, no uso comum "cosmopolita" é "freqüentemente contrastado com patriota". 
Revista de Antropologia, São Paulo, USP, 2002, v. 45 no 1.

E sse é precisamente o caráter "judaico" que gostaria de desenvolver a seguir e, no entanto, elogiar. Cosmopolitismo, sugerirei, é um hábito mental, propensão e prática dotados de importância vital para a inculcação de uma ordem social global "pós-nacional" - no ethos, mesmo que não ainda institucionalmente. A noção de ser hóspede em qualquer ambiente social particular - hóspede, por assim dizer, dos procedimentos sociais que possibilitam a contratuação da hospedagem mútua - coloca em questão uma ordem social à qual todos podem pertencer e sentir que pertencem.

O advento do pós-nacionalismo - no contexto de arranjos institucionais como a União Européia e de desarranjos como os nacionalismos étnicos nos Bálcãs, no Cáucaso e no O riente Médio - é algo ao mesmo tempo fácil de imaginar e forçado. Mas muitos comentadores passaram a encarar os processos de centripetismo global e de centrifugismo regional como dois aspectos de uma mesma transformação milenar: uma globalização que torna os nacionalismos dos últimos dois séculos obsoletos, apesar de, no meio termo, esses nacionalismos poderem ser substituídos por virulentos particularismos renascentes. Nesse sentido, estamos legitimados a utilizar as nossas imaginações antropológicas no intuito de refletir sobre arranjos sociais para essa condição pós-nacional, global. Com efeito, de acordo com Emest G ellner (1993), nesse quesito temos pouca opção. O compartilhamento de uma condição humana global é um fato da vida de todos nós, e aspirar a outra coisa com base em qualquer perspectiva espúria, pós-colonial ou culturalmente relativista, seria caricaturar a realidade e negligenciar nossa tarefa profissional. Qualquer antropologia "adequada" teria de partir da natureza completamente "transcultural" do mundo contemporâneo - dos seus arranjos e conhecimentos institucionais - e trabalhar no intuito de instituir uma moralidade transcultural (: 54). Com certeza, isso não é fácil; pode ser incrivelmente difícil, mas seria precisamente esse o nosso dilema: "descobrir as opções sociais implícitas à nossa condição de riqueza e de desencantamento" (1995: 8). 
G ostaria de dar um primeiro passo nessa direção sugerindo um local no qual a ordem social pós-nacional pode ser imaginada em seus fundamentos: a cosmopolis, a cidade-mundo. Esse é o cenário natural para 0 encontro de viajantes globais, multiculturais, sob a égide de procedimentos universais e com base em associações contratuais. A cosmopolis, mais exatamente a cidade-mundo e o seu interior regional - o que Pahl chamou de domínio de "aldeias metropolitanas" (1968: 269) - pode encerrar um todo pós-nacional complexo. É um cenário para facilidades urbanas num espaço relativamente disperso - "urbs in rure" ou "urbs et rus", como dizem os planejadores -, onde pode florescer um ethos cultural no qual as partes envolvidas substituam noções e idiomas de autóctones e alienígenas por contratos locais, estabelecendo relações de igualdade político-legal, de "hóspedes mútuos" que participam de trocas locais.

\section{0 imaginánio urbano}

$\mathrm{H}$ osts and guests [A nfitriões e hóspedes] é o título de uma bem-conhecida antologia de artigos editada por Valene Smith, sobre turistas e os - às vezes longamente sofredores - habitantes das regiões que os primeiros visitam. Smith define o turista como "uma pessoa temporariamente ociosa que visita voluntariamente um lugar longe de casa a fim de experienciar uma mudança" (1989: 1). Talvez, no entanto, o que mais tenha caracterizado a avaliação antropológica do turismo desde 0 texto de Smith tenha sido a importância fundamental desse fenômeno para a compreensão do mundo contemporâneo como tal. A experiência "temporária" do "lazer" por "pessoas longe de casa" tornou-se central em termos teóricos, de forma que agora envolve a experiência, ordinária e extraordinária, de todos nós (G raburn, 1988). "Viajar", mudar de casa ou movimentar-se entre uma casa e outra (o mudar-se como lar) e "experienciar mudanças", é praticado por muitos e traz conseqüências para todos; e o resultado é que não é nem fácil nem sábio tentar delimitar ou diferenciar, de forma absoluta, "anfitriões" de "hóspedes". 
Revista de Antropologia, São Paulo, USP, 2002, v. 45 no 1.

Além disso, uma reciprocidade e periodicidade dos papéis de anfitriões e hóspedes conduzem a um estado no qual nenhuma das partes está clara ou absolutamente "em casa" em lugar nenhum, ou no qual se está em casa em e através do estar "longe". Reconhecer, no contexto do multiculturalismo e movimento global contemporâneo (turismo, migração por razões de trabalho, peregrinação, exílio), a fluidez das noções de anfitriões e hóspedes, é também reconhecer a hospedagem mútua como papel normativo exercido no espaço social: onde quem está "em casa" é uma questão da natureza e do intuito das trocas particulares, mais do que de identidades absolutas. Isso, com certeza, também vai de encontro a uma longa tradição de teorizações sociais que igualmente conceberam um futuro possível de associação voluntária global, de pertencimento, como derivado de contratos sociais assumidos a partir de uma base deliberada, mútua e serial. Tanto Henry Maine quanto Ferdinand Toennies assinalaram uma transição possível de ordens sociais localmente indexadas para outras capazes de abarcar a generosidade global ou cosmopolita. Transições de status para "contrato" (Maine, 1861) e de "comunidade" para "associação" (Toennies, [1887] 1957) apontam, de formas similares, para a esperança num tempo em que as relações sejam rotineiramente travadas e reguladas em termos instrumentais, imparciais e recíprocos, a fim de garantir a condução de negócios específicos e com base em posições de voluntarismo legalmente assegurado.

Ao mesmo tempo, a associação contratual conta com um conluio inconfundivelmente em voga. Políticas e economias de "apostadores" integram as políticas de governo em ambos os lados do Atlântico; e rapidamente se desenvolvem noções de contratos a serem aplicados em domínios apenas vagamente pré-definidos por lei e de proveniência mais "tradicional". Há os discutíveis casos de contratos entre pais e filhos, entre filhos e escolas, entre médicos e pacientes, entre prestadores de serviços e consumidores, entre cidadãos e seus governos.

Adotando o espírito do cosmopolitismo, considero, em geral, essa contratualização da vida social uma "coisa boa", deixando de lado 
detalhes referentes a qual partido político tem um programa mais apropriado para a sua implementação. Ao mesmo tempo, os ecos de Toennies e Maine nos lembram de que essas mudanças supostamente já estiveram em curso por um certo tempo, e que também é questionável o quanto as previsões e prescrições oitocentistas (incluindo as de SaintSimon, Marx e D urkheim) acerca da evolução sociocultural ideal-típica são práticas às quais se gostaria de ver o próprio nome associado ou que se gostaria de ver sendo repetidas. Recorrer à generalização, à oposição binária e à progressão unilinear não apenas desemboca numa ciência social pobre, mas também traz consigo o risco de que as idéias sejam arrogantemente repudiadas ou inescrupulosamente aplicadas.

Também estou ciente de que não é suficiente para superar a generalidade, a reivindicação da cidade como lugar principal onde a ideologia global e a prática local podem se encontrar, onde os indivíduos em trânsito podem ter uma relação contratual uns com os outros para atuarem como hóspedes mútuos; por mais que a reivindicação restrinja o foco dessa concepção de futuro. De fato, na história do imaginário ocidental, é possível afirmar que a cidade ocupe um lugar especial; cidades há muito tempo são "boas para pensar" - com os mais variados resultados.

Exemplificar, muito brevemente, a natureza "totêmica" da cidade ocidental não se faz sem lembrar que a cidade-estado modelar defendida por Platão (1963) é decididamente um ambiente autoritário, no qual uma república perfeita é concebida segundo os termos de uma elite dirigente educada para a apreensão intelectual daquilo que é "bom", e que governa para assegurar a maior "felicidade" do todo por meio de censura e de diferenciação social. Para Milton, entretanto, rememorar a polis de Platão significa vislumbrar o genuíno "olho da G récia [antiga]", mãe das artes, da eloqüência, da inteligência, de hospitalidade e estudo (1932: livro IV, linhas 240-47). G oethe (1949), por sua vez, remete-se à cidade-estado antiga para distanciá-la dos tempos e necessidades presentes: enquanto a pólis teria prescrito lealidades e exclusividades 
Revista de Antropologia, São Paulo, USP, 2002, v. 45 noํ 1.

por ser uma pátria à parte e distinta, 0 "patriotismo" atual apelaria para um intercurso constante entre nações, da mesma forma como a vida urbana se ajustaria adequadamente ao provimento. Para uma testemunha anterior, William Penn (1726), a distinção pertinente não seria tanto entre a pólis clássica e as condições modernas, e sim entre 0 urbano e 0 rural: "a vida no campo deve ser preferida, porque lá vemos as obras de D eus, porém nas cidades pouco mais do que as obras dos homens". Igualmente, na descrição que Dickens faz de "Coketown", a cidade como aglomeração industrial arquetípica se transforma grotescamente em lar de tudo aquilo que é essencialmente não-natural, do confinamento, da doença e da ganância:

aquela cidadela feia, da qual a Natureza era tão intensamente exluída quanto incluídos os ares e gases mortíferos; no coração do labirinto de mais e mais vielas estreitas, de mais e mais ruas densas, que tinham começado a existir aos pedaços, cada pedaço numa pressa violenta para servir aalgum propósito humano, e o todo, uma família não-natural, empurrando e esmagando e pressionando os pedaços uns sobre os outros até a morte. (1971: 102)

Para Robert Park, por sua vez, membro fundador da escola de sociologia de Chicago, a dicotomização idiomática entre o rural e o urbano permanece, mas agora se favorece 0 engenhoso e contemporâneo em detrimento do originário e popular [folky]. D esenvolvendo as percepções de seu professor G eorg Simmel, Park esboça a cidade como ambiente social e moral que abrigaria o futuro; ambiente onde tipos muito diferentes de pessoas se encontrariam e misturariam (ainda que sem uma completa compreensão mútua), onde os contatos entre as pessoas seriam freqüentemente transitórios, casuais, fortuitos e instáveis, e onde o status seria em geral uma questão de apresentação, de modos e de elegância. Em conjunto, a cidade dos tempos modernos - Chicago par ex callenœ - chegaria a ser designada, em algum momento, "habitat natural do homem civilizado", realizando a promessa proverbial medieval de que "o ar da cidade conduz à liberdade" (Park, 1968: 3). Por fim, para o geógrafo humano Harvey Cox, na "cidade secular" os seres humanos 
assumiriam a responsabilidade pelos espaços que proporcionariam desenvolvimento, variedade e orientação às suas vidas; o secularismo urbano "expulsa antigas opressões e subverte convenções embrutecedoras. Ele desloca a vida social e cultural do homem em direção a ele, demandando um dispêndio constante de visão e competência" (1965: 86).

Para além da qualidade intertextual dessas referências, do modo como as primeiras contextualizam as últimas, o que esse meu mapeamento por demais breve de fato acaba por elucidar é a maleabilidade da cidade como item de reflexão sócio-filosófica. 0 próprio Park observou como as cidades costumam assumir as características e qualidades dos seus habitantes, sendo assim inerentemente diversas, e mais recentemente Jonathan Raban chamou a atenção para o que ele designa como "suavidade" das cidades (1973; também cf. Hannerz (1980: 249)). Um ambiente urbano é suave, explica Raban, pelo fato de se transformar naquilo que as pessoas fazem dele; a cidade espera os habitantes e observadores moldarem-na num certo formato, enquanto pouco incorpora em e de si mesmo. Cidades assumiriam um formato em torno dos habitantes individuais de acordo com as escolhas desses últimos, em meio a um repertório quase infinito e mutável de papéis possíveis. Uma vez que habitantes e observadores tenham decidido, então a cidade assume uma certa fixidez, refletindo a identidade que lhe foi atribuída; se eles se abstêm de imprimir-se no ambiente urbano, permanecerão à margem e à deriva, já que as cidades não oferecem âncoras e alicerces sólidos próprios. Em suma: as estruturas sociais das cidades seriam indeterminadas e amorfas, e estas abrigariam um amplo leque de vidas, corporificando um potencial para a diversidade que é ao mesmo tempo motivo de sonhos e de pesadelos. Plástica por natureza, conclui Raban, tanto a ocupação das cidades quanto a conceptualização dessas resulta num ordenamento contínuo, criativo. Para aqueles desprovidos de fé continuada na visão criativa das cidades ou sem recursos para tornar efetiva essa visão, a suavidade urbana pode ser ameaçadora; pode tornar 
os sem-teto ou pobres urbanos, os habitantes das favelas em São Paulo, no Cairo ou em Manila tudo menos invisíveis aos olhos dos abastados.

Se não é o caso de assumir uma concepção essencialista de ambiente urbano (ou de qualquer outro ambiente) - argumentando em favor de um "modo [necessariamente] urbano de vida" (conforme Louis Wirth (1938), um dos colegas de Park $)^{5}$, mais "suave" do que outros - , de fato, serve aos meus propósitos que as cidades tenham sido e ainda sejam imaginativamente construídas dessa forma, em termos explicativos. Admitido que estamos diante d'“a cidade" como idioma - frente à frente com a república ideal, com o idílio rural, com o cenário civilizado dos sonhos - e não com um descritor essencial de espaços, ambientes ou de vidas efetivas, o imaginário urbano é útil aqui também. Como espaço suave, humanamente construído, maleável e contemporâneo em sua conceptualização, "a cidade" proporciona-me a possibilidade de vislumbrar a cosmópole pós-nacional da hospedagem mútua.

\section{A cidade pós-nacional}

Tendo discorrido sobre a vaguidão ou indistinção da cidade criticamente conceptualizada (Rapport \& O vering, 2000), deixe-me apresentar uma definição vaga, emprestada de Ulf Hannerz:

um povoamento de tamanho considerável, denso, em cujo espaço físico mais ou menos comum prevalece um relativamente alto nível de acessibilidade entre um número relativamente grande de pessoas. (1980: 243)

Hannerz enxerga a cidade como indicativa de uma "tendência centrípeta" num ambiente regional particular. E, enquanto a $\mathrm{G}$ rã-Bretanha em meados do século XIX provavelmente foi o primeiro ambiente sociocultural no qual a maioria das pessoas viveram em cidades e metrópoles, estima-se hoje em dia que mais da metade da população mundial seja urbana. Não há qualquer sinal de que essa tendência esteja se revertendo, ou de que as populações urbanas estejam decrescendo; algumas dúzias de cidades atualmente conseguem vangloriar-se de contarem com 
populações de mais de 15 milhões de habitantes. Mesmo naquelas regiões do O cidente onde se fala de movimentos contra-urbanizadores - a assim chamada "rururbanização" de lugares rurais por ex-moradores urbanos - , o que acontece é uma dispersão dos encantos e estilos de vida urbanos por uma área mais ampla: "urbs in rure" (para relembrar Pahl uma vez mais).

É por isso que Hannerz e outros deram atenção significativa às cidades modernas. Também atribuíram às cidades um lugar especial no interior do tráfico internacional de significados (como coloca Hannerz (1987)), o que evidencia (e é responsável pelo incentivo a) um sistema sociocultural mundial ou "ecúmeno global". Já certas metrópoles - Londres, Miami, Paris - , Hannerz as descreve como ambientes "internacionais" tout court. Nesses, empreendedores, trabalhadores migrantes, estudantes, exilados, turistas se misturariam com "residentes" em trocas dialógicas. Tais cidades se tornam cenários sociais pelos quais fluiriam práticas culturais e onde seriam acolhidas novas formas criolizadas. Hannerz descreve uma nova "cultura metropolitana", relativa, com efeito, a essas cidades internacionais, e que seja reconhecida como diversa das formas "rurais" e "rústicas", menos "sofisticadas" ou "modernas" que a teriam precedido. No entanto, 0 autor resiste ao anseio de tratar 0 urbano e 0 rural, mesmo que idiomaticamente, como dois (tipos de) sistemas sociais discretos e opostos; diferentemente, concebe as relações sociais em termos de um conjunto abrangente de estruturas globais - econômicas, políticas, estéticas, morais. Pode-se imaginar, conclui Hannerz (1987), um espectro global, criolizado, que conecta a metrópole primeiromundista à aldeia terceiro-mundista. Uma conversação flui ao longo desse espectro, de sorte que formas culturais diversas se engrenam e se amalgamam, comentam e parodiam, influenciam e subvertem umas as outras, em entremesclas e contrapontos infinitos. E dessa troca recíproca ninguém está excluído: "estamos todos sendo criolizados" (: 557).

Se práticas e símbolos são, na imagem de Hannerz, continuamente traficados pelas cidades internacionais, sendo transformados e criolizados 
Revista de Antro pologia, São Paulo, USP, 2002, v. 45 no 1.

ao longo do processo, então isso se dá, parcialmente pelo menos, porque as pessoas estão em contínuo movimento por e no interior desses espaços urbanos. Um senso difuso de mobilidade ligado a isso caracteriza a vida urbana, já que os habitantes, em trânsito por mundos sociais múltiplos e diversificados (casa e trabalho, família e amigos, religião e recriação), acham conexões, evitam relações, encontram pessoas, armazenam experiências, rotinizam o espaço e escapam à rotina. Cidades são "paisagens migrantes", nas palavras de Chambers (1994: 14, 94), lar de "transformações, misturas, contaminações, experimentações, revisitações e recomposições", recompondo histórias e tradições, alterando centros e periferias, misturando tendências globais e distinções locais. As cidades são lugares de transformações da realidade social, de vidas transitórias e de movimentos culturais.

Um elemento importante trazido também para o primeiro plano por meio da noção de Hannerz da cidade internacional, como lugar para 0 tráfico global de significados, é a natureza experiencial desse ambiente, e a qualidade necessariamente interpretativa da abordagem antropológica deste. A cidade como "cidade-mundo", 0 ambiente sociocultural como parte de um ecúmeno global, movimento e troca como indicativos de uma rede de alcance mundial: esses são assuntos tanto de julgamento quanto de medição. Eles são, ademais, de importância vital para a apreensão antropológica do urbanismo contemporâneo e do que este pode vir a se tornar. $\mathrm{O}$ significado da cidade para os seus habitantes e observadores possui uma qualidade, uma realidade na vida humana, que é tão significativa quanto a aparente objetividade e fixidez da cidade em mapas e estatísticas - se não mais do que isso.

Isso vale especialmente para a minha busca por uma possível imagemde-futuro do pós-nacional em meio ao metropolitano-internacional contemporâneo. Não me interessa tanto a acurácia mensurável dos detalhes da mudança, presente na descrição que Hannerz faz da modernização via criolização. Instiga-me, sim, o lugar que 0 autor reserva à cosmópole. Se o que me importa é ver na cidade internacional não 
apenas o cenário de um ecúmeno global, mas também o protótipo de uma cultura de cosmopolitismo numa ordem social pós-nacional, então é significativo que Hannerz e seus informantes atribuam certos significados à forma social. "A cidade" é um símbolo significativo cujo uso pode servir de percurso a certos acontecimentos; o discurso da "cidade internacional como ecúmeno global" pode adquirir força elocutória para criar certos fatos sociais - para criar a cidade pós-nacional como realidade objetiva.

Se a minha concepção sobre a existência de hóspedes mútuos em meio aos procedimentos justos da cidade pós-nacional deve ser mais do que um castelo de cartas, então tem-se de avaliar o processo discursivo através do qual as pessoas empregam o simbólico na negociação e construção (e reconstrução) do social-estrutural. É necessário entender, conforme assinalou Cohen (1993), que as pessoas são responsáveis por inventar cidades com cultura - elas enculturam [enculture] a cidade; não respondem passivamente a esta como força determinística. Tanto quanto quaisquer outros, os ambientes urbanos são constituídos por (e não constitutivos dos) "eus" [selves] dos seus habitantes individuais, e os seus significados - os significados das vidas vividas no interior desses ambientes - não podem ser generalizados. É errado imaginar um ambiente urbano como necessariamente massificante e que anonimiza os indivíduos (à la Wirth) fraturando-os, por exemplo, em papéis, segmentando-os à propos de mundos sociais diferentes. Isso apenas reduziria os habitantes de uma cidade a símbolos-zero da lógica que um analista (ou administrador) utilizaria para modelar a vida social urbana no intuito de abarcá-la. Na verdade, tem de ser avaliado como "as pessoas modelam a cidade através da sua inventividade cotidiana" (: 8), sendo o seu envolvimento menos uma questão de imperativo coercitivo do que de transação, organização e aquisição deliberada de recursos (Amit-Talai, 1989). Em suma: é porque a cidade é uma forma simbólica significativa que as pessoas animam e informam através de sua experiência e uso contínuos - algo que os indivíduos dotam de 
Revista de Antropologia, São Paulo, USP, 2002, v. 45 no 1.

sentido no contexto de suas circunstâncias pessoais - , que a noção de cidade pós-nacional pode ser mais do que mero wishful thinking.

\section{Uma etnografia da cidade}

"As multidões, a confusão e o rumor constante da conversação jocosa" significam, para Geertz (1960: 49), que os ambientes urbanos acabam por estar imbuídos de uma certa qualidade elusiva, quase impossível de se apreender sistematicamente. Para Hannerz há, entretanto, uma solução, passível de ser encontrada analisando-se a série de redes de interação urbana; as cidade são retratadas como "redes de redes", numa colagem mutável de indivíduos, papéis, domínios culturais e situações sociais de troca (1980: 200; cf. também Sanjek (1978)).

Numa etnografia da cidade canadense de St. John's, na província de Newfoundland, empenhei-me em rastrear a rede de conexões referente ao modo como indivíduos em diferentes cenários urbanos conversavam sobre "violência" (Rapport, 1987). Analisando as categorias, idiossincrasias e diversidades implícitas ao "debater violência" - a violência dos roubos armados, da polícia; a violência nos bares, em torno das drogas, contra as mulheres e numa possível guerra nuclear -, senti que poderia apreender como as pessoas se juntavam de formas variadas em St. John's no intuito de incentivar e desenvolver diferentes tipos de relações, antes de novamente retornarem aos seus itinerários pessoais dentro da cidade e fora dela. "Violência" era um nódulo de comunicação em torno do qual a conversação se organizava regular e convenientemente; divisa que tornava trocas conversacionais transitórias (potencialmente inseguras) previsíveis e rotineiras. Falar da incerteza de uma forma habitual engendrava a certeza.

Minha impressão foi de que, na cidade contemporânea, a condução das relações sociais era mais uma questão de trocas verbais do que de qualquer outra coisa; e mais, de troca verbal mais ou menos formularizada [formulaic] em seu caráter. Eram palavras que indivíduos em trânsito 
global por e entre ambientes socioculturais conseguiam mais facilmente carregar consigo e encarar como fontes de estabilidade, como recordações de relações e tempos passados, como indicativos de portos seguros no presente. Mais do que isso: no dar e receber da troca conversacional do assumir a própria vez, do retratar e ser retratado - , residiam uma mutualidade e igualdade intrínsecas. Os conversadores atuavam como hóspedes mútuos em relação às incursões, subterfúgios e inferências verbais uns dos outros. Conforme aponta John Berger, os indivíduos estão em casa na cidade num conjunto de práticas habitualmente repetidas, amplamente conversacionais: "palavras, piadas, opiniões, gestos, ações, mesmo o modo como se usa um chapéu" (1984: 64).

O quadro que emergiu em St. John's foi o de um ambiente sociocultural constituído por um fundo comum de divisas-em-uso, e que servia de anfitrião para acordos e desacordos mutantes sobre como os indivíduos habitualmente escolhiam juntar-se em torno dessas divisas e conversar. Mergulhando nesse universo à medida em que cruzavam o espaço urbano, os indivíduos desenvolviam relações de variável intimidade e complexidade verbal-cum-social, encontrando-se em níveis variados de inclusividade verbal-cum-social. Estava em jogo uma escala móvel de similaridade e diferença verbais (Rapport, 1994a). Como cidade, St. John's encerrava uma comunidade fraseológica, sendo que divisas, clichês e fórmulas de troca constituíam a moeda relativamente comum e estável por meio da qual uma população globalmente transitória conseguia fixar-se para os propósitos de troca local.

Uma exemplificação particular disso está na descrição de um dia 8 de maio - Dia da Independência de Israel - que passei em St. John's em meados dos anos 80, em companhia de alguns membros da comunidade judaica do lugar. É importante ressaltar que Newfoundland (compreendendo a ilha de Newfoundland e o território continental de Labrador), fundada em 1497, foi a primeira colônia inglesa da região, tornando-se parte do Canadá apenas em 1949. Além disso, mantém a reputação de ser a "Província Não-Tem" ["H aveN ot Provinœ"] do Canadá. É que, com o seu clima rude, a distância em relação aos principais 
Revista de Antropologia, São Paulo, USP, 2002, v. 45 no 1.

mercados, a história de exploração e de subdesenvolvimento mercantis e sua economia atual pouco viável (baseada que é na decadente pesca de bacalhau dos $G$ rand Banks, sendo complementada apenas pela derrubada de árvores e transporte de toras, pela mineração e pelo petróleo), as oportunidades de emprego em Newfoundland permanecem bastante irregulares. A taxa de desemprego pode chegar a 35\%; e com o emprego freqüentemente sendo, na melhor das hipóteses, sazonal, a dependência em relação a investimentos e iniciativas de bem-estar implementados por fontes externas, principalmente pelo governo federal em 0 ttawa, pode parecer endêmica.

Noventa porcento da população de Newfoundland permanecem de origem inglesa e irlandesa (os nativos indígenas são tidos como uma casualidade antiga). No entanto, St. John's, a capital da província, com uma população de 150 mil habitantes (do total de 600 mil que moram na ilha), possui uma ambiência mais multicultural e abastada, pontilhada por etnicidades chegadas mais recentemente: vietnamitas, chineses, gregos, europeus orientais, cubanos, paquistaneses, filipinos, italianos e judeus.

A comunidade judaica de Newfoundland é pequena, mas economicamente bem estabelecida; a partir da sua base em St. John's, ela tem dotado a ilha de empresas de atacado e varejo voltadas para roupas e eletro-eletrônicos (Kahn, 1987) ${ }^{6}$. Impelidos por pogroms da Europa O riental, os primeiros povoadores judeus de que se tem registro chegaram a Newfoundland nos anos 1890. A comunidade chegou ao seu tamanho máximo depois da Segunda $G$ uerra Mundial, mas desde então os números têm decaído, com as crianças ali crescidas seguindo uma trajetória imigrante comum e transferindo-se para 0 - mais lucrativo - continente canadense (e os seus pais, quando aposentados, vão para perto deles, se não para a Flórida ou a Califórnia) (Gold, 1987). Nos anos 80, havia apenas algo como vinte famílias judaicas ali, de forma que, numa região que no passado abrigara duas sinagogas, era cada vez mais difícil arcar com o sustento e a manutenção de um rabino. 
O casionalmente, contudo, as crianças ali crescidas de fato permanecem e trabalham na ilha. D entre essas encontra-se Israel (Izzy) Horovitz, atualmente na faixa dos 25 anos e empregado como engenheiro do D epartamento de Recursos, Minas e Energia do governo provincial. Além disso, em anos recentes esses indivíduos caseiros passaram a contar com a companhia de alguns adultos judeus jovens do continente (na maioria, solteiros), que chegaram a St. John's para concluir sua formação superior na St. John's' Memorial University, ali ensinar ou fazer estágios (em medicina ou direito, freqüentemente), antes de retornarem ao tumulto do continente, mais competitivo. Para essas pessoas, ir para Newfoundland é mais como experienciar um "país de Terceiro Mundo", oferecendo a este os seus talentos e serviços (Rapport, 1994b). D entre esses indivíduos estão Mirium Hagentasch (terapeuta ocupacional nascida em Montreal e que agora está entrando na faixa dos trinta), Nathan Bloom (professor de ciências da computação na universidade e com cerca de 35 anos de idade, nascido em Toronto mas residente em St.John's háalguns anos) e Howard Simons (que largou a universidade, agora perto dos trinta, tendo permanecido em Newfoundland vivendo de biscates tais como a pintura de casas). Nigel, antropólogo da G rãBretanha, também recentemente juntou-se ao círculo social dessas pessoas.

Essa "Noite de Israel", em particular, encontrou a maioria da comunidade judaica congregada no hall da sinagoga, para um jantar formal. A isso se sucederam um espetáculo de dança folclórica israelense (por um grupo basicamente composto de jovens adultos do continente); uma hora, dançada por todos; um leilão de velas de aniversário e de um bolo visando a arrecadação de dinheiro em prol do Estado de Israel e de seu renascimento; e, ao final, um ou dois discursos:

PA U L JA CO BS (Presidente da Sinagoga): "Hoje, como sabemos, é o $37^{\circ}$ aniversário de Israel. É também, obviamente, o V E D ay ['D ia da V itória na E uropa', da capitulação alemã, em 8 de maio de 1945]; portanto haverá celebrações paralelas à nossa em todas as principais cidades canadenses. [A plausos] G ostaria de convidar Lionel LaRusic para nos dizer algumas palavras". 
L ION E L L A RU SIC (culto e respeitado membro da comunidade, sobrevivente de Auschwitz): "Nós somos a geração abençoada; nós vimos o renascimento do Estado de Israel depois de desejar isso por cerca de 64 gerações. Peço desculpas ao rabino, mas nós já testemunhamos parte da Chegada do Messias! E nós todos nos sentimos mais seguros sabendo que Israel está aí".

Q uando terminam os eventos na sinagoga são 22:15 horas, e Izzy, Mirium, Nathan e Nigel decidem ir a um bar do centro para um pequeno drinque. O ptam pela atmosfera relaxada do Kibitzers, e lá encontram sem querer o seu amigo Howard, que também está ali para tomar um gole antes de dormir:

ISRA E L : "Howard Simons! Engraçado que você tenha saído para beber aqui sem ir à [sinagoga] Shul para a noite de Israel" .

H OW A RD : "É uma daquelas decisões morais difíceis: ir à Shul ou divertirse! [Eles riem]".

MIRIU M : "E seráa mesmacoisano C anada D ay [D ia do Canadá] em Pleasantville: ou vejo os meus amigos apresentarem um espetáculo de dança israelense ao lado de cerca de quatorze outros grupos étnicos! - , ou assisto a um espetáculo fantástico de fogos de artifício fora do hall”!

ISRA E L : "É como: por quem você lutaria se Israel e o Canadá entrassem em guerra"!?

N A TH A N :[rindo] "Eu não diria que faz parte da mesma categoria de decisões morais sérias, Izzy"!

MIRIU M: "E tampouco muito prováveis".

N IG E L : "Você acha que conseguiria viver em Israel novamente, Izzy"?

ISRA E L : "Bem, eu estive lá por alguns anos enquanto era adolescente, mas conseguir um trabalho lá agora seria difícil para mim".

N IG E L : "O s seus pais não poderiam ajudar"?

ISRA E L : "Não de fato. Eu não teria quaisquer contatos, porque meu pai nunca viveu lá. A penas minha mãe". 
N A TH A N : "Eu acharia bastante difícil viver em Israel exatamente agora. É que algumas das políticas governamentais parecem tão odiáveis. Como na Cisjordânia. D eve ser um pouco como o apartheid sul-africano: eles anexam a área e depois chamam todo judeu que lá vive de 'cidadão', mas não todo árabe".

M IRIU M : "Não, sem essa. Você deveria vêla, Nathan. A Cisjordânia éuma área tão minúscula: e um rebuliço tão grande éfeito em tomo dela!Já superou qualquer limite. É uma parte tão pequena do país, mas só se fala dela hoje em dia. Mas sem brincadeira: é um problema pequeno num lugar pequeno".

N A TH A N : "Eu meenvolvi nisso, Mirium. [...]E também vi quantos milhões de dólares foram investidos ali. Eles nunca vão ser capazes de devolver. E todos aqueles edifícios e a infra-estrutura: não é como o Sinai. Então, nesse caso, 0 que eles vão fazer com os árabes? Não podem fazer deles cidadãos, senão em quarenta anos Israel será dominada pelos árabes - com as suas taxas de natalidade. Então, o que eles vão fazer com os árabes? No momento eles não possuem direitos de cidadania"!

M IRIU M : "E o que vocêfaria”?

N A TH A N : "Não sei. Hoje em dia, os israelenses se acostumaram também a usar a água fluvial da margem esquerda do Jordão" .

ISRA E L : "Eles deveriam ter avançado até D amasco em 1967, quando tinham a chance, e não, parado. Assim não haveria toda essa confusão com a Síria e a O LP atualmente".

N A TH A N : [ri] "Sim. Isso também teria sido uma solução! Seriamente, entretanto, eu não penso que poderia viver em Israel agora. Isto é, o Canadá é, de maneira geral, um lugar tão equilibrado, comparativamente. Mas em Israel você sente a violência borbulhar todo o tempo".

ISRA E L : "Eu posso dizer a vocês que não sentiria a violência, se tivesse um bom emprego de vendedor numa empresa de discos"!

N IG E L : "Com o seu próprio suprimento de música e fitas, eu sei".

ISRA E L : "Bem, eles ainda não fazem discos em Israel, mas há empresas fazendo equipamentos médicos e computadores de alta tecnologia, e eu poderia ser vendedor para alguém desse tipo. G ostaria de vender esse tipo decoisa - e falar inglês seria uma vantagem, porque eles vendem para o mundo anglófono. Portanto, talvez isso me agradasse.[...] Mas nesse caso será que eu precisaria fazer um MBA antes? Por exemplo, em Toronto, ou mesmo em Israel? Provavelmente isso me tomaria dois anos". 
NIG E L : "De voltaà universidade”!

ISRA E L : "Sim: Eu provavelmente conseguiria agüentar a vida universitária por esse tempo. D evo admitir que estava bastante farto do trabalho universitário, e de falar sobre ele todo o tempo, enquanto fazia engenharia na M UN [M emorial U niversity of N ewfoundland]. Mas, então, um MBA não é como um programa de engenharia ou como a vida normal na universidade. [...] Mas, então, dois anos de universidade me custariam 100 mil dólares, em parte pelos custos e em parte pelo que eu perderia não trabalhando".

N IG E L : "Mas essa não éa maneira de se pensar nisso".

N A TH A N : "Você sabia que o programa de engenharia aqui originalmente foi idealizado por um cara da U of T [U niversity of T oronto], Izzy? Eu o conheci bastante bem. E a universidade não é mal cotada; certamente conta com um um bom programa cooperativo".

ISRA E L : "É verdade. Pode não ser tão acadêmica, mas possui um bom renome na indústria. Eu estive na M cG ill [U niversity, em M ontreal] por um ano, mas aquilo me pareceu tudo matemática e física".

N A TH A N : “O que me espanta nesse caso, contudo, é a falta de retorno dos alunos, nas aulas expositivas: não há perguntas, ninguém corrige erros - à exceção de pessoas como D avid Cohen, que sempre corrige você, e isso é ótimo: mostra que ele está acompanhando e o que ele entende. Mas o resto... Você às vezes se pergunta se eles ainda estão vivos" !

ISRA E L : "Essa é a mentalidade local: nunca pergunte, a não ser que você esteja $100 \%$ seguro".

M IRIU M : "Eu culpo a educação religiosa por isso. Eles são ensinados apenas a aceitar tudo e a não questionar nada".

N A TH A N : "Quantos anos no total você viveu aqui até hoje, Mirium”?

M IRIU M : "Sete anos agora”.

N A TH A N : “Uau!Vocêé quase uma N ewfie! Uma nativa”.

M IRIU M : "Não. Eu ainda sou uma montrealense. Pergunteao Izzy. E acho que gosto cada vez menos da cultura local quanto mais tempo fico aqui e começo a conhecêla, de alguma forma. Não sei. Parece tão defensiva e contra o que é de fora; e também antiintelectual". 
N A TH A N : "Estava me perguntando como um bar chamado Kibitzers chega a estar aqui. Isto é, é uma palavra ídiche. [...] E como eles a pronunciam errado o nome! Kibitzers em vez de Kibitzers".

ISRA E L : "Nunca realmente gostei de vir beber aqui, porque alguém foi assassinado aqui, sabe? [O s outros parecem surpresos.] Sim [baixando a voz]; alguém chamado D oug Skinner foi esfaqueado. Ele estava trabalhando atrás do balcão. Houve um grande furor em relação a isso naquele tempo. Ninguém entendeu como exatamente aconteceu - ou mesmo por quê. O u mesmo se eles se conheciam uns aos outros - porque ele estava morto. E houve um rebuliço terrivelmente grande: é que não há muito desse tipo de coisa aqui".

N A TH A N : "Eu quase me envolvi numa briga do lado de fora do Peppers na última sexta-feira! Eu estava na fila às cinco da tarde- havia uma fila porque era happy hour. D e fato era besteira eu estar lá, porque não havia fila do lado de fora do Fishing Admiral. D e qualquer forma, havia três de nós esperando: eu, D avid Cohen e Fred, e depois de vinte minutos nós tinhamos chegado ao segundo lugar dafila; apenas um cara na frente da gente. Então um bêbado vem caminhando do outro lado da rua e fica parado exatamente do meu lado e começa a bater papo - para furar a fila. Cinco minutos mais tarde ele ainda está lá, e eu não tinha dito uma palavra: ele não tinha conseguido me fazer falar. Então eu tiro os meus cigarros, porque eu sei que ele me pedirá um, e ele pede e eu digo: 'Absolutamente não'"'!

M IRIU M : “G ostei do 'absolutamente"”!

ISRA E L : “Oh, caramba! Já posso imaginar o que está por vir”.

N A TH A N : "Sim, eu disse 'A bsolutamente não! É que você furou a fila'. Então ele sai e volta cinco minutos mais tarde com um maço de cigarros, e agora fica de pé exatamente na frente da fila, com o primeiro cara, e oferecelhe um cigarro e lhe pergunta se 'aquele chato' que não tinha lhe dado um cigarro antes já entrou. Então eu disse: 'Não. Eu ainda estou aqui... E ainda não acho que você tenha o direito de furar a fila'. Então o cara me diz: 'Você está vivo por acidente, companheiro! Cuidado'. D e qualquer forma, eu não agüentava mais, então sugeri que todos nós fôssemos ao Fishing Admiral, e foi o que fizemos"!

ISRA E L : "Essa foi por um triz. Você deve ser louco, Nath"!

N A TH A N : "Mas eu estou aborrecido comigo, agora. Naquele momento eu estava bastante satisfeito. [...] Mas eu deveria ter avisado o segurança ou 
procurado um carro de polícia de passagem e lhes falado sobre esse bêbado me incomodando. O bviamente, se a polícia não tivesse parado - então, eu teria de ter quebrado as janelas do carro ou coisa do gênero para fazer os policiais me levarem embora com eles! É que eu não poderia ter ficado com o bêbado, enquanto eles fossem embora. [Todos riem.] Eu vou estar no centro de Halifax por três dias em breve. Você, que conhece, Howard, o que acha que eu deveria visitar lá”?

H OW A RD : "Oh, você deveria procurar se divertir bastante! O s bares de Halifax são um pouco como aqui. Mas a quantidade é maior e são bares mais sofisticados".

N A THA N : "Mas antes disso visitarei um clínico geral amigo meu em Carbonnear".

ISRAEL: "Carbonnear fica a um pulo do centro de Halifax, meu filho"!

N A TH A N : "Meu amigo me disse que lá em Carbonnear há três categorias de dor. Uma é 'isso é uma certa dor!'; a segunda (pior) é 'isso é uma dor cruel!'; e a terceira, 'oh, meu filho! Isso é uma dor!'.. [Eles riem.]

ISRA E L : [enquanto a garçonete se aproxima para retirar da mesa os copose garrafas vazias] "Alguém quer mais"?

M IRIU M : "Izzy! Acho horrível o quanto você bebe hoje em dia! Vocênão fazia isso a um ano atrás".

N IG E L : "Mas é apenas 'Miller Lite'. Só bolhas e água”.

ISRA E L : [falando hebraico, já que a garçonete ainda está presente] "Então, o que vocês acham dessas pernas embaixo do vestido? Elas seguem direitinho o seu caminho para dentro da roupa"!

M IRIU M : [simulando estar chocada] "Izzy”!

N A TH A N : “Esqueça ele! O brigada, senhorita. [...] Então, depois de Halifax, a minha próxima viagem, no verão, é para os Estados Unidos; tenho de pesquisar em Nova Iorque e em Los Angeles entrevistando empregados de algumas grandes corporações e comparando o uso que fazem de computadores, e como são afetados por diferentes estruturas administrativas. Depois, finalmente, volto a Toronto para ver a minha mãe, e como vai o seu câncer...". 
O que gostaria de assinalar, ao refletir sobre essa história, é a transitoriedade das identificações locais em relação às quais os seus participantes periodicamente atuam como anfitriões: uma ambigüidade que gostaria de definir como cosmopolita. A mais óbvia delas é a celebração da "Noite de Israel" a uma distância de muitos milhares de milhas de Israel, por parte de uma congregação judaica em Newfoundland; congregação esta criada por pessoas nascidas na própria Newfoundland, no continente norte-americano, na Europa e na África do Sul. Conforme declarado após o jantar, todos esses indivíduos conseguem se sentir mais seguros no Canadá devido à existência de Israel. Ao mesmo tempo, contudo, é sugerido que a lembrança do aniversário de Israel é mediada pela de celebrações que os indivíduos sabem que estão acontecendo simultaneamente em todo o Canadá, em memória à vitória contra o Nazismo na Segunda G uerra Mundial. Além disso, a comunidade judaica que se encontra numa sinagoga específica de Newfoundland inchou significativamente por causa de um número de jovens do continente que trazem consigo a percepção de que "o judaísmo é algo pelo qual se tem de trabalhar, não apenas algo dentro do qual se nasce e basta" (Rachel Fernstein). São esses jovens, ademais, que atualmente emprestam sua energia à celebração judaica pública em St. John's, animando-a com teatro judaico e dança folclórica israelense - inclusive representando " $O$ s Canadenses Israelenses de Newfoundland" no "Festival de Vida Folk" ["F olk-L ife F estival"] do Dia do Canadá, em 1 de julho -, o instrutor de dança e estrela-guia do grupo é um estudante não-judeu de folclore de Vancouver: "Portanto, não é mais apenas etnicidade" (Rachel Fernstein).

Transportadas para o bar do centro, as questões ligadas às lealdades relacionais e à responsabilidade moral aparecem amplamente na discussão. D ever-se-ia sair sozinho para o pub numa noite como essa, sem juntarse à comunidade na Shul? D ever-se-ia assistir a um espetáculo de dança israelense produzido por iguais, se isso significa perder o suntuoso espetáculo de fogos de artifício do Dia do Canadá? Q ual, em geral, o lugar que Israel e o Canadá ocupam nas afeições de cada um? Essas questões, portanto, integram uma gama mais ampla de outras, concer- 
Revista de Antropologia, São Paulo, USP, 2002, v. 45 no 1.

nentes ao lugar do mundo em que se deveria gostar de viver, trabalhar, estudar e que se gostaria de visitar. O Canadá continental, os EUA, Newfoundland e Israel exercem, cada um, a sua atração, e todos os falantes podem recorrer a histórias pessoais ou familiares sobre viagens globais: todos mantêm contatos, relações e contratos de pesquisa em outro lugar. Também proeminente nas deliberações desses indivíduos é a noção de cidadania e o que esta deveria englobar. 0 Canadá parece exemplificar mais igualdade e segurança individual do que outros lugares - inclusive Israel, onde a violência está sempre nas entrelinhas. Mas, afinal, seriam os outros lugares tão diferentes? Até Newfoundland, aparentemente, com a sua reputação para a pacatez, conta com seus assassinos ousados e suas brigas de rua cotidianas.

A demais, a cultura provinciana de Newfoundland, plena de educação escolar religiosa e de cultos de obediência, deixa muito a desejar quando contrastada com a do continente. No entanto, Izzy pode reivindicar ser um $\mathrm{N}$ ewfie, nascido e criado ali, ao menos em comparação com os outros, enquanto Nathan encara Mirium, com os seus sete anos de residência na região, como bastante nativa ela mesma, ostentando ter participado, ele mesmo, da vida de Newfoundland por muito mais tempo do que Howard ou Nigel. Para Mirium, todavia, os anos passados residindo ali de fato não se traduzem em identidade local; quanto mais tempo ela permanece, mais alienada, de fato, ela se sente, ressentindose do ajuste aos costumes locais, cuja demonstração cabal seria a inclinação de Izzy pela cerveja. Izzy, por sua vez, distancia-se ele próprio das relações locais ao falar hebraico na frente e a respeito de uma garçonete graciosa, enquanto Nathan atenua essa impolidez apenas para questionar-se acerca da importação e má pronúncia de uma palavra ídiche como nome de um bar local, e para achar graça em como idiomas provincianos exprimem a dor. Por fim, Nathan envolve todos numa discussão que liga a vida em St. John's com os bares de Halifax, na Nova Escócia, com a pesquisa da cultura computacional nos EUA, e com a visita à família em Toronto. 
A fluidez e as incertezas da discussão acima parecem refletir as incertezas e a fluidez mais gerais de se viver na "Província Não-Tem" do Canadá: onde a decisão relativamente recente de pertencer ao Estadonação do continente (1949) ainda é uma questão usual de debate - a "Província Não-É" ["BeN ot Province"]? -; onde, de fato, a existência continuada do Estado-nação per se é o assunto mais usual do discurso político do continente (Paine, 1981: 19). E onde "refletir" discursivamente sobre a fluidez e as incertezas é recriar e realizá-las. Por meio de suas trocas conversacionais, Nathan, Izzy, Mirium, Howard e Nigel mantêm as suas relações ambíguas com entidades tais como Newfoundland e 0 Canadá, e mantêm o status e as relações ambíguas desse para com aquele.

Hóspedes mútuos das réplicas conversacionais uns aos outros, Izzy, Mirium, Nathan, Howard e Nigel também pertencem a uma série de identidades locais-aum-globais. Num bar que parece ídiche, no Dia da Independência de Israel, numa cidade provincial inserida em mercados econômicos, educacionais e morais globais, esses indivíduos participam de relações verbais locais (baseadas na troca rotineira de expressões formularizadas concernentes a tópicos clichê de debate) através das quais a transitoriedade global é mediada. Minha sugestão é de que ambigüidades de identidade como essas deitem discursivamente as bases de um possível cosmopolitismo pós-nacionalista.

\section{Conclusão}

Há um aparente ponto cego ou contradição no âmago deste texto, que gostaria de abordar à guisa de conclusão. Meu intuito tinha sido examinar o que o idioma formularizado do "judeu errante" poderia render em matéria das descrições de multiculturalismo, transnacionalismo e cosmopolitismo existentes no mundo contemporâneo, e de prescrições para um possivelmente viável pós-nacionalismo. Argumentei que 0 idioma revela pouco sobre as vidas dos judeus como indivíduos. No decorrer do texto, contudo, recorri precisamente aos judeus como exemplificação de uma tese sobre os "judeus" como potenciais pós- 
Revista de Antropologia, São Paulo, USP, 2002, v. 45 no 1.

nacionalistas. Mas que tipo de prova é essa? Como apostar numa ampla teoria de pós-nacionalismo global por meio de uma exemplificação baseada nos cosmopolitas arquetípicos do mundo? Além disso, por mais transnacionais que pareçam os judeus pesquisados, eles estão longe de serem pós-nacionalistas. Sua fala é temperada por sentimentos chauvinistas e essencialismos de coloração nacionalista sobre o "Canadá", "Israel", "N ewfies" e "árabes"; suas identidades se hiearquizam em classificações criadoras de O utros ["othering" classifications], estando tão longe de serem individuais nelas mesmas quanto genuinamente hospitaleiras a outras identificações. Por fim, tal como é, o transnacionalismo desses indivíduos funda-se numa abundância e segurança que lhes permite viajar e pontificar, considerar migrações e avaliar opções de uma maneira que é impossível para os seus vizinhos locais em Newfoundland e, menos ainda, para os pobres da Cisjordânia.

A fim de me contrapor a essa interpretação, eu reiteraria a distinção entre judeus e o "judeu errante". O judeus não mais detêm o monopólio sobre os instintos de viagem ou de cosmopolitismo - isso, se eles já o detiveram algum dia ${ }^{7}$. A noção de judeu "errante" arquetípico tem de agora ceder espaço etnográfico para gregos (Moskos, 1989) e palestinos viajantes (Gonzalez, 1992); isso para não falar de bailarinos (Wulff, 1998) e consultores financeiros (Amit-Talai, 1998). Em segundo lugar, não são apenas os ricos que viajam; seria simplificar demais argumentar que o transnacionalismo é um índice de riqueza, quando os migrantes em busca de trabalho freqüentemente se encontram dentre os setores mais pobres da humanidade (Lloyd, 1979), e quando os camponeses irlandeses tiveram tanto sucesso com isso - seja em Newfoundland ou não (Mannion, 1977).

Em terceiro lugar, focar o aparente arquétipo - o judeu como cosmopolita típico - é revelar a distância entre as classificações essencialistas e os conteúdos de fato da vida social. 0 efeito do discurso é moldar os contornos formais de um ambiente social - e oposições e exagerações estereotípicas podem exercer o importante papel de subsidiar essas construções (Rapport, 1995) - , mas a vida é vivida nos detalhes que 
residem entre a forma e o significado. No âmbito da classe formal dos "judeus", encontram-se judeus individuais que são mais diferentes do que parecidos entre si. Diria então que não é por alguma automaticidade ou regularidade ou necessidade particular que Izzy, Mirium, Nathan, Howard e Nigel se encontram em companhia uns dos outros em St. John's. A sua judaicidade com efeito não os torna parceiros óbvios ou naturais ou especialmente casuais de conversa, e na sua "judaicidade", nos seus sentimentos por Israel, na sua experiência de não-judaicidade, em todas as coisas que formalmente sinalizam a sua semelhança categorial, a individualidade de cada um sobrepuja aquilo que têm em comum (Rapport, 1994b).

Por fim, então, o que dizer das exclusividades comunitárias aparentes que congregam Izzy, Mirium, Nathan, Howard e Nigel na "Noite de Israel", primeiro no hall da sinagoga e depois no Kibitzers, capacitandoos abertamente a discutir as suas identidades e idéias sobre as relações entre Newfoundland, o Canadá, Israel e os EUA sem embaraços ou medo de censura? A meu ver, o que importa é que, ao prescrever o pósnacionalismo, não se precisa imaginar o domínio absoluto do chauvinismo, e sim, a ironia deste. Noções absolutas de identidade tornamse contingentes, ao serem contextualizadas ao lado de outras: uma identidade de um conjunto de outras que contratam por espaço no mesmo lugar, uma identidade de um conjunto de outras em torno das quais os mesmos indivíduos contratam um pertencimento. E enquanto se pode objetar que não há nada de particularmente "pós" nessa caracterização - que o sentimento e a afiliação nacionalistas sempre foram acompanhados no cotidiano por ceticismo, ironia e auto-sarcasmo, e que, afora situações de crise e de emergência, foram cerceados por associações contraditórias no nível da região, da comunidade, da família e assim por diante (Conversa pessoal com Amit em 12 de junho de 2000) - , 0 rótulo "pós-nacionalismo", contudo, privilegia um novo tipo possível de legitimação, rotulando formalmente um acréscimo de identidade. Ao mover-se periodicamente entre um certo número de identidades absolutas e chauvinistas, e entre tais identidades e outras não-absolutistas, 
Revista de Antropologia, São Paulo, USP, 2002, v. 45 no 1.

0 absolutismo só pode ser vivido ironicamente. É que só se está em casa no seu "próprio" lugar na medida em que outros estão ao mesmo tempo em casa nos seus lugares - e esses "lugares" ocupam o mesmo espaço ${ }^{8}$. Neste momento final do texto, vejo como positivo 0 anteriormente apresentado malabarismo de absolutismos, de identidades comunitárias canadenses e israelenses, de Newfoundland e do continente. É que a possibilidade e experiência de um absolutismo nunca estão ausentes do momento em que se acolhe um outro; e o resultado é que nenhum absolutismo é absolutamente ele mesmo, e cada absolutismo é relativizado pelos outros. 0 indivíduo que se torna irônico em relação aos seus próprios chauvinismos contrastivos permite-se admiti-los apenas na medida em que permite aos outros fazê-lo também. $O$ que se deve almejar, em termos antropológicos, é uma formalização dos procedimentos (pós-nacionalistas) por meio dos quais fique legalmente garantida a ironia da identidade e dos direitos absolutos, além de assegurado o direito mútuo a uma contratação da hospedagem.

Pode-se contra-argumentar (fazendo ecoar Kundera) que uma ironia final é que há muito nessa prescrição que se sobrepõe às descrições do Estado de Israel tal como ele já existe. Em sua equânime abordagem do que ele chamava, então, de nação "compósita", Emanuel Marx (1980) determinava que se deveria conseguir explicar as inequivalências entre "nação", "estado" e "sociedade" em "Israel", e as contingências e a fluidez da procedência desses termos. "Israel", Marx explica, pode ser retratado como uma série de agregados sociais parcialmente sobrepostos, bastante diferentes uns dos outros, que funcionam como sistemas mais ou menos abertos cujas fronteiras variam de situação para situação. 0 "Estado" resulta numa quantidade de organizações concorrentes (instituições, funcionalismo e objetivos) que o tornam tudo menos monolítico. "Nação" não equivale nem a "Israel" nem a "Estado" e tem de ser concebida como entidade plural desprovida de fronteiras geográficas delimitadas. "Sociedade", por fim, é um sistema multidimensional cujas sub-unidades, novamente, estão longe de serem claramente limitadas em termos territoriais, e que depende de uma quantidade 
de premissas e ideologias amplamente aceitas para persistir. Como formulado de maneira mais poética pelo novelista Amos Oz (1992), Israel não é um país ou uma nação, e não se pode derivar dele nenhum "quadro representativo" ou "cruzamento típico". É, antes, uma coleção veemente de argumentos; ajuntamento penetrante de cerca de cinco milhões de profetas e primeiros-ministros todos concentrados em transcender a categorização, em superar o hermetismo institucional e em escapar aos sistemas absolutos (imagináveis) (Rapport, 1998b: 81)9.

Para alguns, a descrição de Israel acima apresentada provavelmente relegue esse texto ao reino das imaginações utópicas. Para aqueles com noções apenas passageiras, o questionamento interno endêmico sobre como lidar com a ameaça contínua à sobrevivência física - que constitui o discurso mais rotineiro compartilhado pelos membros da comunidade do Estado de Israel - é obscurecido pelo impacto externo de uma eficiente Força D efensiva israelense. Mesmo para aqueles dotados de simpatia pelo lugar, como G eorge Steiner, conceber a missão "judaica" em termos de hospedagem mútua coloca em questão "o significado verdadeiro de Israel, um significado muito menos universal do que o do judaísmo" (: 15). 0 que eu diria para finalizar é que, num mundo pautado em movimento, a cidade, mais exatamente a cosmopolis numa rede global de conexões, oferece uma moldura institucional melhor do que o Estado-nação para abrigar um mundo de hóspedes. A relativa pequenez das cidades e sua profusão numérica assegurarão de forma melhor que as pessoas exerçam o papel de hóspedes de espaços sociais, que procedam uns em relação aos outros de forma usual e rotineira e que, assim, resistam à tentação de um absolutismo irrefletido. A cosmopolis pode servir para promover um despojamento irônico, que poderá, em contrapartida, alimentar uma generosidade do espírito, de forma que a hospedagem se transforme em uma expectativa e prática cotidiana não associada meramente ao turista superprivilegiado ou ao refugiado subprivilegiado.

Tradução: Fraya Frehse 


\section{Notas}

1 Segundo John Berger (1984: 55), por sua vez, "a emigração é a experiência quintessencial de nosso tempo".

2 Ou, nos termos de Trinh Minh-ha, "a era atual é marcada pelo exílio" (1994: 1314).

3 G handi, por exemplo, prescrevia a paz etno-religiosa na Índia baseando-se na concepção de que os hindus educariam as crianças muçulmanasa serem muçulmanas ortodoxas e vice-versa.

4 Conferir Amit-Talai e Rapport (2001), para um desenvolvimento mais detalhado do utopismo antropológico aqui mencionado.

5 D efinindo a cidade como "povoamento relativamente grande, denso epermanente de indivíduos socialmente heterogêneos", Wirth (1938) retoma Toennies, preconizando um "modo de vida urbano" como substituição de relações rurais duradouras, passíveis de conhecimento e freqüentemente derivadas do parentesco, por relações impessoais, superficiais, segmentadas, não-cumulativas, imprevisíveis e submetidas a uma maior rotatividade.

6 A Congregação Hebraica de Newfoundland foi oficialmente fundada em 1909. Em 1921, totalizava 14 famílias e, em 1934, 37. A primeira sinagoga foi construída em St. John's em 1931. D epois da Segunda Guerra Mundial e do influxo de soldados aliados, além de refugiados europeus, uma segunda sinagoga foi aberta na cidade de Corner Brook.

7 Vered A mité da opinião de que os judeus nunca se ajustaram verdadeiramente à caracterização de "cosmopolitas" (Conversa pessoal em 12 de junho de 2000). Nos regimes feudais eles, de formas variadas, se posicionaram para além do escopo normal e normativo dos padrões de status, ao comerciarem na capital e não se prenderem à terra, naquelas que eram sociedades predominantemente regionais. Mas as redes familiares dispersas dos judeus e a sua movimentação física por essas mesmas redes se conservavam, através de hábitos rígidos de endogamia e de fortes estímulos ao enclausuramento étnico [ethnic dosure]. $\mathrm{Na}$ oitocentista sociedade shtetl, até os seus movimentos eram restringidos, enquanto no século XX a conexão de ambientes euro-americanos com o Estado de Israel 
resultou numa forma de nacionalismo desterritorializado. Amit-Talia conclui que o que os judeus de clareza cosmopolita [oosmopolitan openness] demonstraram vai de encontro a tendências assimilacionistas que se traduziram numa atenuação da judaicidade [Jewishness] como tal.

8 Augé argumenta de forma semelhante ao conceber a superação da localidade pelo não-lugar (1995). Não que sejam banidas as noções tradicionais de fixidez, do direito absoluto de certas relações sociais e rotinas culturais a certos lugares, na medida em que a singularidadenormativa da localidadeé destruída. D oravante, a possibilidade e experiência do não-lugarnão está nunca ausente de nenhum lugar, de forma que nenhum lugar é completamente ele mesmo apartado, e nenhum lugar é completamente outro. Lugar e não-lugar representam modalidades contrastivas, este estando sempre disponível para ironizar de forma salutar aquele.

9 É interessante, nesse contexto, relembrar as razões de Sartre para descrever a fundação do Estado de Israel como "um dos eventos mais importantes do nosso tempo, um dos poucos atualmente que nos mantêm esperançosos" (1974: 225). Não apenas Israel poderia representar um refúgio global contra 0 anti-semitismo, mas também uma censura a todos aqueles que invocassem "sangue e solo" para afirmar a identidade. 0 estado judaico contestaria a segurança infundada daqueles que reivindicam alguma ligação especial, mística, com o seu país de origem.

\section{Bibliografia}

AMIT-TALAI, V.

1989 A rmenians in L ondon, Manchester, Manchester University Press.

1998 "Risky hiatuses and the limits of social imagination: Expatriacy in the Cayman Islands", in RAPPORT, N. \& D AWSIN, A. (eds.) M igrants of Identity, Oxford, Berg.

AMIT-TALAI, V. \& RAPPORT, N.

2002 The trouble with community: A nthropological reflections on movement, identity and ollectivity, London, Pluto.

ARENDT, $\mathrm{H}$.

1962 O rigins of totalitarianis, London: Allen \& Unwin. 
AUGÉ, M.

$1995 \quad$ N on-places, London, Verso.

BAUMAN, Z .

1989 Modernity and the holocaust, Ithaca, Cornell University Press.

BERGER, J.

1984 A nd our facs, my heart, brief as photos, London, Writers \& Readers.

BERMANT, C.

$1998 \quad$ G enesis, London, Robson.

CHAMBERS, I.

1994 Migrancy, alture, identity, London, Routledge.

COHEN, A. P.

1993

"Introduction", in COHEN, A. P. \& FUKUI, K. (eds.) H umanising the aity?, Edinburgh, Edinburgh University Press.

$\mathrm{COX}, \mathrm{H}$.

1965 The seaular aty, Toronto, Macmillan.

DICKENS, C.

1971 H ard Times, Harmondsworth, Penguin.

GEERTZ, C.

1960 Thereligion of Java, G lencoe, Free.

GELLNER, E.

$1983 \quad$ N ations and nationalism, Oxford, Blackwell.

1993 Postmodernism, reason and religion, London, Routledge.

1995 "Anything goes: The camival of cheap relativism which threatens to swamp the coming fin de millenaire", T imes L iterary Supplement, vol. 4811: 6-8.

GOETHE, W.

1949 W isdom and ex perienœ, London, Routledge and Kegan Paul. 
GOLD, G.

1987 "A tale of two communities: The growth and decline of small-town Jewish communities in Northern Ontario and Southwestern Louisiana", in RISCHIN, M. (ed.), The Jews of N orth A merica, D etroit, Wayne State University Press.

GONZALEZ, N.

1992 D ollar, doveand eagle, Ann Arbor/ University of Michigan Press.

GRABURN, N. (ED .)

1988 "Anthropological research on contemporary tounism", Kroeber A nthropological Society Papers (Special Issue), vol. 67-68.

HANNERZ, U.

1980 E x ploring the city, New Y ork, Columbia University Press.

1987 "The world in creolization", A frica, vol. 57(4): 546-59.

KAHN, A.

1987

L isten while I tell you, St. John's, ISER Press/ Memorial University.

KIBERD , D .

1998

"Romantic Ireland's dead and gone: The English-Speaking Republic as the crucible of modernity", T imes L iterary Supplement, vol. 4967: 12-14.

KUNDERA, M.

1990 The art of the novel, London, Faber.

LENIN, V. I.

1974 L enin on the Jewish question, New Y ork, International.

LLOYD , P.

1979 Slums of hope, Manchester, Manchester University Press.

MAINE, $\mathrm{H}$.

1861 A ncient L aw, London, Murray.

MANNION, F. (ED.)

1977 The peopling of N ewfoundland, St. John's NFLD, ISER Press/ Memorial University. 
MARX, E.

1980

"On the anthropological study of nations", in MARX, E. (ed.) A composite portrait of Israel, London, Academic.

MILTON, J.

1932

Paradise regained, London, Partridge.

MINH-HA, T.

1994

"O ther than myself/ my other self", in ROBERT SO N, G. et al. (eds.) Travellers' tales, London, Routledge.

MOSKOS, C.

1989

G reek A mericans, New Brunswick, Transaction.

NKOSI, L.

1994

"Ironies of exile: post-colonial homelessness and the anticlimax of retum", Times L iterary Supplement, vol. 4748: 5.

$\mathrm{OZ}, \mathrm{A}$.

1992

"Israeli Literature", The Raymond Williams Lecture, Hay-on Wye Festival of Literature, May 31st.

PAHL, R.

1968

"The rural-urban continuum", in PAHL, R. (ed.) Readings in urban sociology, Oxford, Pergamon.

PAINE, R.

1981

"When saying is doing", in PAINE, R. (ed.) Politically speaking, St. John's, ISER Press/ Memorial University.

1999

"A boriginality, multiculturalism, and liberal rights philosophy", E thnos, vol. 64(3): 325-49.

PARK, R.

1968

"The city: Suggestions for the investigation of human behaviour in the urban environment", in PARK, R. et al. (eds.) Thecity, Chicago, University of Chicago Press. 
PENN, W.

1726 The works of W illiam Penn, London, Sowle.

PLATO

1963 The republic, Cambridge, Cambridge University Press.

RABAN, J.

1973 Soft city, Harmondsworth, Penguin.

RAPPORT, N.J.

1987 Talking violeno. A $n$ anthropological interpretation of onversation in the city, St. John's, ISER Press/ Memorial University.

1994a "'Busted for hash': Common catchwords and individual identities in a Canadian city", in AMIT-TALAI, V. \& LUSTIG ER-THALER, H. (eds.) U rban lives, Toronto, McClelland \& Stewart.

1994b "Traumaand ego-syntonic response: The holocaust and the Newfoundland Young Yids', 1985", in HEALD , S. \& DULUZ, A. (eds.) A nthropology and psychoanalysis, London, Routledge.

1995 "Migrant selves and stereotypes: Personal context in a postmodern world", in PILE, S. \& THRIFT, N. (eds.) M apping the subject, London, Routledge.

1998a "Thepotential of human rights in a post-cultural world", Social A nthropology, vol. 6(3): 381-88.

1998b "Coming home to adream: A study of the immigrant discourse of 'AngloSaxons' in Israel", in RAPPO RT, N. \& D AWSO N, A. (eds.) M igrants of identity, Oxford, Berg.

RAPPORT, N.J. \& DAWSO N, A. (ED S.)

1998 Migrants of identity. Perceptions of home in a world of movement, O xford, Berg.

RAPPORT, N. J. \& OVERING, J.

2000 Social and altural anthropology. Key concepts, London, Routledge.

SANJEK, R.

1978 "A network method and its uses in urban ethnography", H uman 0 rganization, vol. 37: 257-68. 
SARTRE, J-P.

1974

The writings of Jean-Paul Sartre, vol. 2, Evanston, Northestern University Press.

SMITH, V.

1989

"Introduction", in SMITH, V. (ed.) H osts and guests, Philadelphia, University of Pennsylvania Press.

SPENCER, J.

1997

"Nationalism", in BARNARD , A. \& SPENCER, J. (eds.) The ecydopaedic dictionary of social and cultural anthropology, London, Routledge.

STEINER, G.

1998

"War, terrorism and chaos: G od's idea of keeping a promise", The 0 bserver Review, February 22: 15.

TEDLOCK, B.

1996

"Diasporas"', in LEVINSO N, D \& \& EMBER, M. (eds.) The encydopedia of altural anthropology, New York, Holt.

TOENNIES, F.

[1887]1957 Community and society, New Y ork, Harper.

WEINBERG, R.

1998 Stalin's forgotten zion, Berkeley, University of California Press.

WERBNER, P.

1996

"' $O$ ur blood is green': Cricket, identity and social empowerment among British Pakistanis", in MACCLANCY, J. (ed.) Sport, identity and ethnicity, Oxford, Berg.

WIRTH, L.

1938 "Urbanism as a way of life", A merican Journal of Sociology, 44.

WULFF, $\mathrm{H}$.

1998

Ballet across borders, $\mathrm{O}$ xford, Berg. 


\begin{abstract}
As anthropologists describe the increasing normativeness of global movement and the consequent hybridity, creolization, synchronicity and compression of multiculturalism, "diaspora" has become a key tool in the disciplinary armoury. This paper begins from one particular feature in this diasporic accounting, that pertaining to the exilic "WanderingJew".

From an examination of the "Jew" in the discourse of modern nationalism, the paper proceeds to a possible discourse of post-national urbanism, to conclude with an ethnographic account of Jewish lives in the contemporary Canadian milieu of urban Newfoundland.

While the idiom of the "Wandering Jew" might say little about the content of actual individual lives, what, nevertheless, might it be said to contain in the way of political prescription? What political message might the notion of universal (Jewish) cosmopolitanism and transnationalism be seen to hold, and how might this ideal type be employed idealistically by anthropology in the cause of cultural critique? From the idiom of the "Wandering Jew", the paper thus proceeds to an outlining of "mutual guesting" as a conceptualization of just social procedures in a new world system.
\end{abstract}

KEY-WORD S: globalization, post-nationalism, cosmopolitanism, diaspora, Jews, discourse, irony, urbanism, Newfoundland. 